\title{
Communication policies, good governance and development journalism
}

\author{
Jan Servaes*
}

- Abstract

This article tries to problematise the link between communication, governance and development. The critical importance of a free and balanced flow of information to an engaged and active civil society, through an independent media and transparent government, has long been acknowledged. Communication plays a pivotal role in improving governance in developing countries.

The article assesses different communication strategies for the implementation of sustainable development. It distinguishes between short-term and long-term objectives in view of the Millennium Development Goals and new challenges such as globalisation, ICTs and liberalisation. In order to assess this is a more applied way, the article briefly outlines a set of media performance indicators, developed by UNESCO, and refers to recent events in Kenya to argue in favour of a communication for development perspective which focuses on the self-development of local communities. The basic assumption is that there are no countries or communities that function completely autonomously, and that are completely self-sufficient, nor are there any nations whose development is exclusively determined by external factors. Every society and community is dependent in one way or another, both in form and in degree.

Key words: Communication policies, development journalism, good governance, Kenya, media indicators, Millennium Development Goals, right to communicate

Our work is far from over.

Nelson Mandela at 90

Hyde Park, London, 27 June 2008

These are times, the world over, where strong government must give way to better governance; where hierarchical relationships must give way to equal partnerships; where rewarding ethnic cliques must give way to enriching national diversity; and where the tyranny of the majority must give way to a genuine consensus building. Only then Kenya will have a bright and prosperous future Raila Odinga, Prime Minister of Kenya Safari-Park Hotel, Nairobi, 2 July 2008

\section{INTRODUCTION}

The early phase of development communication was marked by Daniel Lerner's (1958) modernisation paradigm, the basic idea of which is that mass media and mass communication stimulate

\footnotetext{
* Jan Servaes is professor and chair of the Department of Communication, University of Massachusetts, Amherst MA, USA. E-mail: Freenet002@gmail.com This article is based on a keynote paper for the Workshop on 'Economic Policy and Development Journalism', Office of the Prime Minister \& Office of the President, July 1-5, 2008, Nairobi, Kenya.
} 
and diffuse values and institutions that are favourable to achievement, mobility, innovation and consumption. According to modernisation theory, the developed world played an important role in modernising and facilitating economic development in the developing world. The mass media were seen as being instrumental in achieving this goal, as it was believed that media messages had a powerful impact in these underdeveloped societies. The media were seen as the 'mobility multipliers' (Schramm 1964) or 'diffusers of innovations' (Rogers 1962, 1983, 2003). Servaes (1999) and others (e.g. Melkote 1991; Sparks 2007) have noted that this model was essentially elitist and a top-down process. The assumptions on which the modernisation paradigm was built, linger on and continue to influence the policy and planning-making discourse of major actors in the field of communication for development, both at theoretical and applied levels (Berger 2004; Fraser \& Restrepo 1998).

During the 1960s and 70s, a second major stream of development communication developed in the dependency paradigm. The theory was based on the belief that the wealthy, developed nations of the so-called Center relied on a poorer group of nations in the Periphery to remain wealthy (Fox 1988; Kay 1989). The dependency and communication paradigm points both to technological and economic dependence on the Center, and to cultural and ideological penetration by Western values and thought patterns (Beltran 1993, Boyd-Barrett 1977, 1982). However, its basic argument is an explicit economic assumption - that is, the state of underdevelopment in the Periphery is determined by the development of the Center (Chilcote \& Johnson 1983; Mehmet 1995).

Today almost nobody would dare to make the optimistic claims of the early years (GumucioDagron \& Tufte 2006). The experience of the past fifty years has demonstrated that development is possible, but not inevitable. Our present-day 'global village', in general as well as in its distinct regional and national entities, is confronted with multifaceted crises: economic and financial, but also social, cultural, ideological, moral, political, ethnic, ecological and security crises. Previously held traditional modernisation and dependency perspectives have become more difficult to support because of the growing interdependency of regions, nations and communities in our globalised world.

As many others, we are in search of a new paradigm for development, one which looks at development as a transformation of society. In such a perspective

change is not an end in itself, but a means to other objectives. The changes that are associated with development provide individuals and societies more control over their own destiny. Development enriches the lives of individuals by widening their horizons and reducing their sense of isolation. It reduces the afflictions brought on by disease and poverty, not only increasing lifespans, but improving the vitality of life. (Stiglitz 1998: 3)

This perspective argues that considerations of communication need to be explicitly built into development plans to ensure that a mutual sharing/learning_process is facilitated. Such com- 
municative sharing is deemed the best guarantee for creating successful transformative projects. We call this new perspective the multiplicity or participation paradigm. Its approach is holistic, employing a number of integrated approaches. Basically, in the multiplicity paradigm, media development is seen as development from below, empowering communities at a local level. The emphasis is on participatory and horizontal communication rather than communication from above (for more details, see Servaes 1999, 2003, 2008).

A similar set of principles and values is also adopted in the United Nations Millennium Declaration (United Nations 2000):

- Freedom: Men and women have the right to live their lives and raise their children in dignity, free from hunger and from the fear of violence, oppression or injustice. Democratic and participatory governance based on the will of the people best assures these rights.

- Equality: No individual and no nation must be denied the opportunity to benefit from development. The equal rights and opportunities of women and men must be assured.

- Solidarity: Global challenges must be managed in a way that distributes the costs and burdens fairly in accordance with the basic principles of equity and social justice. Those who suffer or who benefit least deserve help from those who benefit most.

- Tolerance: Human beings must respect one another, in all their diversity of belief, culture and language. Differences within and between societies should be neither feared nor repressed, but cherished as a precious asset of humanity. A culture of peace and dialogue among all civilizations should be actively promoted.

- Respect for nature: Prudence must be shown in the management of all living species and natural resources, in accordance with the precepts of sustainable development. Only in this way can the immeasurable riches provided to us by nature be preserved and passed on to our descendants. The current unsustainable patterns of production and consumption must be changed in the interest of our future welfare and that of our descendants.

- Shared responsibility: Responsibility for managing worldwide economic and social development, as well as threats to international peace and security, must be shared among the nations of the world and should be exercised multilaterally. As the most universal and most representative organization in the world, the United Nations must play the central role.

Therefore, in contrast to the more economically and politically oriented approach in traditional perspectives on development, the central idea in alternative, more culturally oriented versions is that there is no universal development model which leads to sustainability at all levels of society and the world, that development is an integral, multidimensional and dialectic process that can differ from society to society, community to community, context to context. In other words, each society and community must attempt to delineate its own strategy for sustainable development. 
This implies that the development problem is relative and that no one society can contend that it is 'developed' in every respect.

Therefore, we believe that the scope and degree of interdependency must be studied in relationship with the content of the concept of development. Where previous perspectives did not succeed in reconciling economic growth with social justice, an attempt should be made to approach problems of freedom and justice from the relationship of tension between the individual and the society, and limits of growth and sustainability should be seen as inherent to the interaction between society and its physical and cultural ecology.

Pursuit of this perspective on sustainable development requires the following:

- A political system that secures effective citizen participation in decision making

- An economic system that provides solutions for resolving the tension arising from disharmonious development and growth

- A production system that respects the obligation to preserve the ecological base for development

- A technological system that fosters sustainable patterns of trade and finance

- A legal system that favors the right to free expression and the emergence of free and pluralistic information systems

- An administrative system that is flexible and has the capacity for self-correction

- An education system that encourages critical and creative thinking

- A communication system that gets the development programme organised and accepted by all parties concerned at all levels of society.

\section{COMMUNICATION STRATEGIES FOR THE IMPLEMENTATION OF SUSTAINABLE DEVELOPMENT}

Communication for social change is the nurturing of knowledge aimed at creating a consensus for action that takes into account the interests, needs and capacities of all concerned. It is thus a social process, which has as its ultimate objective sustainable development at distinct levels of society. Communication media and ICTS are important tools in achieving this process, but their use is not an end in itself. Interpersonal and traditional forms of communication must also play a fundamental role.

In Servaes \& Malikhao (2007) we distinguish between five basic development communication approaches: 
(a) Behavior change communication (BCC, emphasis on interpersonal communication)

(b) Mass communication (MC, mix of community media, mass media and ICTs)

(c) Advocacy communication (AC, mix of interpersonal and/or mass communication)

(d) Participatory communication (PC, emphasis on interpersonal communication and community media)

(e) Communication for structural and sustainable social change (CSC, mix of interpersonal communication, participatory communication and mass communication).

For general definitions and assessments of the strengths and weaknesses of interpersonal communication and mass communication, see Knapp \& Daly (2002), McKee, Manoncourt et al. (2000), or McQuail (2005).

At each level different perspectives on the role and place of information and communication for development may apply. Behaviour change communication is mainly concerned with short-term individual changes in attitudes and behaviour. It can be further subdivided in perspectives that explain individual behaviour, interpersonal behaviour, and community or societal behaviour.

Behavioral change communication (BCC), mass communication (MC), and advocacy communication (AC), though useful in itself, will not be able to create sustainable development. Therefore, participatory communication (PC) and communication for structural and sustainable social change (CSC) are more concerned about long-term sustained community change at different levels of society.

At each of the above identified levels, the below two staged processes have to be addressed in parallel ways:

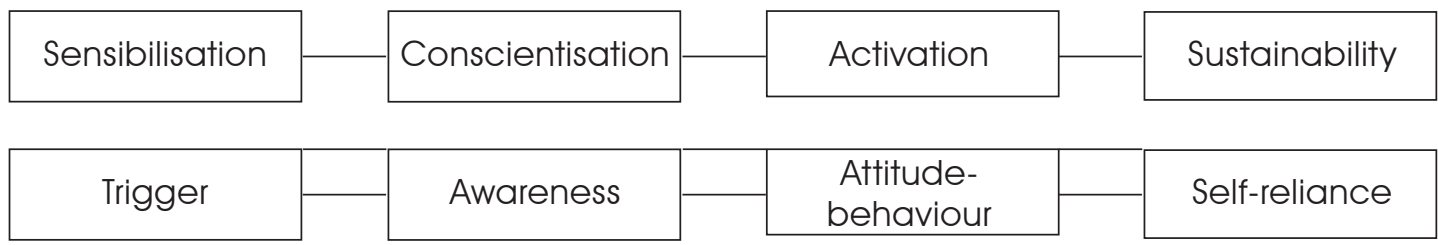

Advocacy seems to be a key action word in current development discourse. However, there is no consensus on a definition of advocacy or the process of advocating. 'The key point is that advocacy seeks to increase the power of people and groups and to make institutions more responsive to human needs' (Wallack 1993: 28). Advocates are usually 'issue' or 'programme' oriented, and do not often think in terms of an on-going process of social change. The resolution of an issue or the initiation of a programme are ends in themselves. Thus, the primary aim of advocacy is to foster public policies that are supportive to the solution of an issue or programme. Since public 
policies must be viewed as an integral part of the social and economic development process, the kind of advocacy we would like to put forward is that which is participatory. The focus in this approach is on 'listening' and 'cooperation' rather than on 'telling what to do' and presumes a dynamic two-way approach to communication.

Therefore, a general working definition of advocacy might be:

Advocacy for development is a combination of social actions designed to gain political commitment, policy support, social acceptance and systems support for a particular goal or programme. It involves collecting and structuring information into a persuasive case; communicating the case to decision-makers and other potential supporters, including the public, through various interpersonal and media channels; and stimulating actions by social institutions, stakeholders and policy-makers in support of the goal or programme. (Servaes 1993: 2)

The communication media are critical in creating awareness, generating public interest and demand, and placing the issue on the public agenda and building social support. They can play two kinds of advocacy roles: (a) they can support development initiatives by the dissemination of messages that encourage the public to support development-oriented projects; and (b) they can provide decision makers with the information and feedback needed to reach a decision. Policymakers usually respond to popular appeal, to pressure groups, and to their own social network of policy- and decision makers. Therefore, advocacy, political commitment and supportive policies are often themselves a product of social support systems and empowerment of people. Advocacy should therefore be viewed in conjunction with social support and empowerment strategies (for more details, see Servaes 2000).

\section{Communication for structural and sustainable change}

As argued, behavioural change communication and advocacy communication, though useful in themselves, will not be able to create sustainable development. This can only be achieved in combination with and by incorporating aspects of the wider environment that influences (and constrains) structural and sustainable change. These aspects include:

- Structural and conjunctural factors (e.g. history, migration, conflicts)

- Policy and legislation

- Service provision

- $\quad$ Education systems

- Institutional and organisational factors (e.g. bureaucracy, corruption) 
- Cultural factors (e.g. religion, norms and values)

- Socio-demographic factors (e.g. ethnicity, class)

- Socio-political factors

- $\quad$ Socio-economic factors, and the

- Physical environment.

These aspects could also be grouped under capital assets, as follows (DFID 2001):

- Human capital: the knowledge, skills and abilities of individuals and groups

- Social capital: relationships, networks, collective norms, social organisation

- Natural capital: natural resources, environmental quality, biodiversity

- Physical capital: infrastructure, housing, energy, facilities, producer goods, communications

- Financial capital: financial resources, available stocks, regular inflows of money.

All these aspects and assets need to be transformed through (policy, legislative, institutional and cultural) processes which lead to structural and sustainable change at the levels of the public and private/commercial sector and civil society (Figueroa, Kincaid et al. 2002).

Inagaki (2007), who reviewed the available empirical research on devcom projects, arrives at a similar conclusion:

When measured alone a mass media message may have negligible direct impacts, but the same message can have significantly greater impacts when mediated through other channels of communication, such as interpersonal communication and group communication. These lessons warn against making generalizations about the effectiveness of a given approach or channel, and call the attention of communication specialists and researchers to contextual factors (emphasis added, JS). (2007: 35)

\section{GLOBALISATION, CULTURAL IDENTITY AND COMMUNICATION RIGHTS}

Globalisation has not fundamentally altered the above situation (Edelman \& Haugurud 2005). However, it is fair to say that communication has been facing new challenges in the last decade, as a consequence of globalisation, media liberalisation, rapid economic and social change, and the emergence of new information and communication technologies (ICTs). Liberalisation has led not only to greater media freedom, but also to the emergence of an increasingly consumer-led and urban-centered communication infrastructure, which is less and less interested in the con- 
cerns of the poor and rural people. Women and other vulnerable groups continue to experience marginalisation, and lack of access to communication resources of all kinds (Lee 1995, 2004).

Article 19 of the Universal Declaration of Human Rights guarantees that 'Everyone has the right to freedom of opinion and expression; this right includes freedom to hold opinions without interference and to seek, receive and impart information and ideas through any media, and regardless of frontiers' (Panos 2007a).

Implied in Article 19 is the connotation that the media are potential champions of the poor, oppressed, and politically suppressed. However, in the 60 years since the Declaration of Human Rights was promulgated, reality has often been sadly at variance with these intentions.

Now, in a $21^{\text {st }}$-century society where the means of communication have developed exponentially, possibilities for community empowerment and access to information have also expanded. The furtherance of media and communication processes in support of increased information flows, accountability of governmental authorities, transparency, anti-corruption measures, and increased democratic reform that guarantees political participation for all citizens, are all now firmly on the governance agenda. The issue of ensuring access to information and the right to communication as a pre-condition for empowering marginalised groups has since been addressed by several meetings and international conferences. (Examples are the African Charter on Broadcasting 2001; the World Summit on the Information Society 2005, or STREAM African framework for the development of a sustainable and pluralistic media 2006. For more details, see Panos 2007b.)

Debates in the general field of 'international and intercultural communication' have shifted and broadened. They have shifted in the sense that they are now focusing on issues related to 'global culture,' 'local culture,' '(post)modernity' and 'multiculturalism' instead of their previous concern with 'modernisation,' 'synchronisation' and 'cultural imperialism' (Martin Barbero 1993). With these 'new' discussions, the debates have also shifted from an emphasis on homogeneity towards an emphasis on differences (De Cuellar 1995; Miller 1995).

Diversity not only exists between cultures, but also within cultures. All cultures are plural, creole, hybrid and multicultural from within. There are no (more) authentic, pure, traditional and isolated cultures in the world, if they ever existed at all (Lie 2003; Nederveen Pieterse \& Parekh 1995). In relation to the media, this means that perspectives need no longer be monistic, but assessed from a multiplicity approach, and media have to be looked at in combined ways, such as in multimedia approaches (Mayo \& Servaes 1994; Melkote 1991; Oepen 1995).

\section{Broadcasting and development communication}

Broadcasting, and particularly radio broadcasting, is widely acknowledged as one of the most powerful means in communication for development for social change (Lewis 1993). Manyozo (2006: 14) has pointed out that 'for many developing nations ... radio is the only reliable av- 
enue for information and knowledge exchange, as it is a readily available, affordable, pervasive, immediate and extensive medium that the majority of socially and economically marginalized citizens can afford'. Yet, as Librero notes, the potential of development broadcasting as a significant factor in development has often been neglected by development planners. 'Maybe this is because development broadcasting, as a concept, has not fully been understood as a potent means of informing people and stirring mass community action' (Librero 2006: 9) (see also Berque, Foy \& Girard 1993; Girard 1992).

In order to provide some legislative framework for best practice in broadcasting policies, Buckley, Duer, Mendel and O'Siochru (2008) take a people-centered approach and address some of the most pertinent issues to create the conditions needed for effective participatory communication. They acknowledge the media's role in the alleviation of poverty, transparency, accountable governance, empowerment and participation for sustainable development. The book makes a number of very useful suggestions for developing policies which will encourage increased public participation in the communication process. In keeping with more of a dependency approach, however, much attention is given to the top-down approach.

\section{Community media}

Within the multiplicity perspective, community media need to be appreciated as a major form of media from a people's or community's perspective for development (Berrigan 1977, 1979; Husband 1994; Lewis 1993, 2008; Servaes \& Liu 2007).

The concept of 'community media' (CM) has shown to be, in its long theoretical and empirical tradition, highly elusive. The multiplicity of media organisations that carry this name has caused most mono-theoretical approaches to focus on certain characteristics, while ignoring other aspects of the identity of community media. This theoretical problem necessitates the use of different approaches to the definition of community media (Table 1), which will allow for a complementary emphasis on different aspects of the identity of 'community media' (for an elaboration, see Carpentier, Lie \& Servaes 2001, 2003).

Table 1: Positioning the four theoretical approaches

\begin{tabular}{|l|l|l|}
\hline & Media-centered & Society-centered \\
\hline $\begin{array}{l}\text { Autonomous identity of } \\
\text { CM } \\
\text { (Essentialist) }\end{array}$ & $\begin{array}{l}\text { Approach I: } \\
\text { Serving the community }\end{array}$ & $\begin{array}{l}\text { Approach III: } \\
\text { Part of civil society }\end{array}$ \\
\hline $\begin{array}{l}\text { Identity of CM in relation } \\
\text { to other identities } \\
\text { (Relationalist) }\end{array}$ & $\begin{array}{l}\text { Approach II: } \\
\text { An alternative to mainstream }\end{array}$ & $\begin{array}{l}\text { Approach IV: } \\
\text { Rhizome }\end{array}$ \\
\hline
\end{tabular}




\section{THE RIGHT TO COMMUNICATE}

It needs to be emphasised that even the best policies may not work if they do not go hand in hand with an environment where a government has regard for these laws. In developing what it calls 'A Model Public Service Broadcasting Law', Article 19 (2005) argues a similar point, noting that laws do not exist in a vacuum - the success or failure of much of these depends on the political, social and cultural environment. Perhaps more attention then needs to be given to the 'from below' view, which argues for the communication rights of the individual and community.

The right to communication is offered as a translation of the communication policy of the multiplicity paradigm. This principle, as a fundamental human right, clearly indicates that another communication model necessitates democratisation and thus a redistribution of power on all levels (Fischer 1982; Fischer \& Harms 1983; Lee 2004). The point of departure is not an elitist position, but development from the grass-roots. Even the well-known MacBride Report suggests that the right to communicate 'promises to advance the democratization of communication on all levels - international, national, local, individual' (MacBride 1980: 171).

Fundamental here is the other vision of the role of the authorities in processes of social change (Braman 1995; Held 1993, 1995; Hoover, Venturelli \& Wagner 1993). Unlike the confidence in and respect for the role of the state, which is characteristic of the modernisation and dependency paradigms, the multiplicity paradigm has a rather reserved attitude toward the authorities. Policies, therefore, should be built on more selective participation strategies of dissociation and association (Hamelink 1994; Servaes 1999). Communication rights are, therefore, closely related to human rights (Galtung 1994; Hamelink 2004; UNDP 2004). As Nobel Prize winner Amartya Sen (2004: 20) argues: 'The deciding issue, ultimately, has to be one of democracy. An overarching value must be the need for participatory decision-making on the kind of society people want to live in, based on open discussion, with adequate opportunity for the expression of minority positions.'

The points of difference between the two options and the ideal-typical political consequences following from them are set side by side in Table 2, which makes a political division between $a$ dominant and a pluralistic model (adapted from McQuail 2005: 88). Along with this 'political' distinction goes an implicit distinction between two models of the process by which the top of society is related, by way of mass communication, to the various groups at the bottom. This dominance model could stand for the 'elitist' aims of both the modernisation and dependency paradigms, while the pluralist model is more suitable for the 'basic' needs of the multiplicity perspective.

These two models have fundamentally different policy and planning implications. It makes a great difference whether policy priorities and planning projects are designed and worked out from the perspective of the top or of the grass-roots. This is shown in Table 3 (adapted from Tehranian 1979: 123), which places the two positions next to each other for a number of development and communication objectives. 
Table 2: A comparison between a Dominance and a Pluralism Model

Dominance:

top to bottom
Pluralism:

bottom to top
Societal source

Media

Structure

Production

Content and

ideology

Audience

Effects
Ruling class or

dominant elite

Under concentrated

ownership and of

uniform type

Hierarchical,

bureaucratic

Standardised,

routinised, control-

led, synchronic

Selective and

coherent,

decided from

'above'

Dependent, passive,

organised on

large scale

Strong and

confirmative

of established

social order
Competing political, socio-cultural

interest groups

Many and independent

of each other

Horizontal,

egalitarian

Creative, free,

original, free,

diachronic

Diverse and

competing views,

decided from

'below'

Fragmented, selective,

reactive and active

Numerous,

without consistency or

predictability of

direction. 
Table 3: Development and communication objectives viewed from a top versus bottom perspective

Top perspective

National power and security

Social mobilisation

National identity, integration

and unity

Economic growth (rise in national income)

Political socialisation

Property and business rights

Educational and professional

advance

Information control

Majority rule (where there is

electoral democracy)

Central control and direction

Cultural and artistic direction

(sometimes censorship)

Ideological and cultural

control

Mass media centered

(one-way communication)

Emphasis on solutions

Product oriented
Bottom perspective

Individual choice and freedom

Social mobility

Sub-national (ethnic or

group interest) identity and

solidarity

Income distribution and

social justice

Political participation

Public and consumer rights

Educational and professional

opportunities

Information access

Minority rights

Regional and local autonomy

Cultural and artistic creativity

(sometimes subversive)

Intellectual and artistic

freedom

Multiple communication use

(media and interpersonal

communication)

Emphasis on questions and

problems

Process oriented

\section{GOVERNANCE FOR DEVELOPMENT AND SOCIAL CHANGE}

In recent years, the word 'governance' has been integrated into the language of development and social change. The term has a wide range of connotations and understandings, often depending on the stance of the organisation, body or authority involved.

In one example, Australia's overseas aid agency, AusAID, has a broad view of the subject (www. ausaid.gov.au/keyaid.gover.cfm 2006): 
Effective governance means competent management of a country's resources in a way that is fair, open, accountable and responsive to people's needs.

Good governance is the basic building block for development. It is the most effective investment that Australia can make in promoting sustained growth, improving living standards and reducing poverty. Support for good governance is not restricted to central governments, but must be adopted by service delivery areas of partner governments, local administrations, civil society and the private sector.

In addressing the various constituencies and improving governance, AusAID has targeted five key areas:

- Improved economic and financial management

- Increased public sector effectiveness

- $\quad$ Strengthened law and justice

- Development of civil society

- Strengthened democratic systems.

The World Bank has made governance its central plank in lending decision-making, while some country programmes consist entirely of funds for this sector. In 2005, World Bank lending for governance, public sector reform and rule of law totaled some $\$ 2.9$ billion, constituting $13 \%$ of the bank's new lending for the year.

Apart from specific lending programmes, governance and anti-corruption measures are mainstreamed in all World Bank country strategies - especially in those countries prone to corruption. The bank's work on governance covers anti-corruption, administrative and civil service reform, decentralization, public financial management, tax policy, legal and judicial reform. Demands for good governance are expressed through media development, participation and social accountability measures (World Bank 2006b).

UNESCO (2005) is another international organization with an on-going programme supportive of press freedom and governance. Its 2005 World Press Freedom Day theme was devoted to the subject. The Final Declaration of the global conference stressed that 'independent and pluralistic media are essential for ensuring transparency, accountability and participation as fundamental elements of good governance and human-rights based development'. It also called on UNESCO's Member States (2005) to 'respect the function of the news media as an essential factor in good governance, vital to increasing both transparency and accountability in decision-making processes and to communicating the principles of good governance to society' (http://portal.unesco. org/ci/en/ev.phpURL). 
The dilemma facing the international community in this domain is in translating words into actions through a positive interface with national governments and in-country authorities, and in combating attempts to derail the process and deny the citizenry access to the information needed to improve lives.

\section{DEVELOPMENT COMMUNICATION IN THE FIELD OF GOVERNANCE}

Communication provides the foundation necessary for the facilitation of good governance, through promotion of effective government, accountability and the active engagement of participants in civil society.

Norris and Zinnbauer (2002) argue that independent journalism, as a potential check on the abuse of power, is a necessary but not sufficient means of strengthening good governance and promoting human development. They suggest that these goals are achieved most effectively under two further conditions. First, in societies where channels of mass communications are free and independent of established interests; and second, where there is widespread access to these media.

Puddenphatt (2008: 3) argues that

the absence of state intervention on its own is no guarantee of a rich media environment. On the contrary: to promote a media environment characterized by pluralism and diversity, state intervention is necessary. To guarantee pluralism requires provisions for public broadcasting, commercial broadcast and print media and community-based broadcast and print media.

Furthermore, Davis (2006: 89-93) observes that 'we are presently unable to measure and determine objectively media's influence within societies and specifically its relationship to governance and overall development, country to country'. Davis proposes the development of a Media-Governance Index, which directly relates to the six dimensions of governance as defined by the World Bank. Such an index would be capable of measuring negative as well as positive impacts of media activity, where media behavior is working against governance or even promoting conflict.

This leads Puddenphatt (2008: 10) to conclude that 'At the moment therefore I am not aware of research that conclusively shows the connection between media and governance'.

It is also important to note that good governance and good government are not the same. Good governance is based on the participation of all people concerned. Focusing on the operation of governmental institutions, such as decentralisation, does not go far enough. Decentralisation does not always signify democratisation. In reality, the motives for decentralisation may hide a central authorities' desire to dispense with certain obligations, while tightening their control in other areas. 
In order to promote participation, it is important to reinforce independent and pluralistic media. For media to be able to offer a critical view of government, political and economic systems must enable the media to operate in as open a public sphere as possible. Press freedom is never guaranteed, particularly when media industries are commercialised, even in a democracy. Apart from creating the appropriate political and economic environments for a free press system, it is crucial to educate journalists to the highest ethical and professional standards possible.

These issues are relevant to all media systems, but especially print and broadcasting. They also address ICTs potential to promote governmental transparency and to engage civil society in yet to be defined ways (Hudson 2006). Discussions of relevant media systems must take into account the expectations and aspirations of the communities involved. For the media to provide a useful public sphere for political dialogue, the technological systems, content, and language need to be accessible by local communities. In addition, although most of this discourse tends to focus on the importance of news and information systems, the critical role of popular culture in political socialisation should not be overlooked.

\section{THE LINK BETWEEN COMMUNICATION, GOVERNANCE AND DEVELOPMENT}

The critical importance of a free and balanced flow of information to an engaged and active civil society, through an independent media and transparent government, has long been acknowledged. Communication plays a pivotal role in improving governance in developing countries. Governance may be defined as: (1) the process by which governments are selected, monitored and replaced, (2) the capacity of the government to formulate and implement sound policies effectively, (3) the respect of citizens and the state for the institutions that govern economic, political, and social interactions among them, and (4) the capacity for active and informed economic, social, and political dialogue among citizens within a public sphere.

Communication also enhances public participation. Participation and monitoring mechanisms may be situated in national efforts to improve public sector performance, increase transparency and reduce corruption. A system of checks and balances, in which communication is one of the key elements, is designed to achieve accountability among and within various agencies of government, manage conflicts of interest in the public sector, effectively disperse power through increasing public participation, and limit situations conducive to corrupt behavior. The effective management within the public sector relies upon these systems of accountability (World Bank 2006a).

Governance also incorporates attention to the public sphere, in which informed citizens actively engage in dialogue on political matters. Communication enhances the potential for civil society to hold governmental authorities accountable as well as to engage in political decision making. Empowering citizens to demand accountability and participation in decision making is critical 
to good governance. Participatory communication can only foster in an environment of freedom from political, economic, and social pressures.

The governance theme may be further categorised in terms of the following issues:

a) Public institutions governance

b) Local government and communities

c) Anti-corruption, accountability and institutional transparency

d) Economic reforms and infrastructure for service delivery, and

e) Role of the media in monitoring institutional governance (adapted from Servaes 2007).

\section{Public institutions governance}

The active participation of citizens and civil society groups in policymaking is now widely considered a sound investment and a core element of good governance, as it allows governments to tap wider sources of information and improves the quality and participation of the decisions reached by institutions at all levels. Citizens' participation and civic engagement take several forms, but each has at its core interactive communication models.

According to a number of international organisations, including the OECD and the World Bank, in strengthening their relations with citizens and their participation in policymaking, governments should ensure that information flows and communication channels are complete, objective, reliable, and accessible. More importantly, consultation, participation, and dialogue with citizens should foster active political participation.

Effective communication in public sector institutions is a primary function of institutional performance as well as its leadership (Chemers 2000; Lord \& Brown 2004). It is through clear and consistent communication of the practices, values, and objectives of the various public sector bodies to staff, management and external stakeholders, that the public sector most effectively supports good governance outcomes and contributes to stakeholder confidence in the public sector. In particular, openness, integrity and effective communication are vital prerequisites of good governance. These qualities contribute to, and are implicitly linked with, other principles such as disclosure, commitment and integration, to ensure accountability in the use of public assets in the quest to achieve stated goals and objectives and required performance levels. In the African context, (Nyamnjoh 2005, 2007; UNECA 2005) as in Kenya (Dowden 2008), the leadership issue remains a problem.

Communication can significantly improve public sector performance and policy formulation when members of institutions convey information and engage in dialogue with citizen groups. 
Moreover, communication can play a vital role in facilitating new public sector dynamics, such as cross-agency governance arrangements and policy design, which are becoming more common as public sector organisations and governments seek to address increasingly complex and/ or wide-ranging policy issues. Such arrangements are also facilitated by the application of new information and communication technologies (ICTs) that enable the rapid formation of virtual organisations to perform specific policy or operational tasks.

Commitment to information technology, however, should be based on a critical assessment of local conditions and needs. It should be realistic and not intrusive so as to operate in harmony with existing communication channels in promoting popular participation.

\section{Access to public sector information}

Governance entails public debate and open participatory decision making; hence, the organisation of interest groups and the free exchange of ideas, opinions and information are essential to good governance. Addressing the information and communication needs of the poor and other oppressed groups is also essential, particularly when basic information concerning human rights and entitlements, public services, health, education, employment etc., is lacking. These groups also lack visibility and defining policy priorities and access to resources.

The public sector is the single biggest producer of information in the developing world. Examples are demographic data, economic statistics, geographic information, business information, and local level government information. This information resource has considerable social and economic potential which often remains untapped. Public sector information is an important economic asset: it constitutes raw material for new services, the improvement of existing services, and the facilitation of commerce and trade. The presence of readily available information products, based on public sector information, could greatly facilitate the functioning of society as a whole. There are, however, a number of barriers that hamper the realisation of the full economic and social potential of public sector information in developing countries.

\section{Local government and communities}

There is growing consensus among development agencies, NGOs, and development practitioners, that good local governance creates the conditions for sustainable development and poverty reduction by increasing citizens 'participation in the local development process. Local authorities and civic groups can be influential in delivering quality services to local citizens. If they are to fulfill these roles effectively, good communication is essential to manage and answer the most pressing questions of local development: Do these local government reforms offer new spaces and significantly increase popular participation in governance? Do local governments appreciate the potential embedded in local media? What are groups working on participation doing in relationship to governance? What participatory methods can be used? A growing body 
of literature demonstrates ways citizen input can be linked to policy-making processes and can improve perceptions of local government legitimacy (Renn, Webler \& Wiedemann 1995).

Local governments and citizen participation play a major role in this effort by ensuring more effective and accountable local infrastructure and service delivery for the poor, and by improving dialogue among different entities, including the state, local communities and the private sector. For the past twenty years, the concept of participation has been widely used in local development, referring primarily to community activities. This concept has now been enhanced to incorporate citizenship rights and local democratic governance. Nowhere is this seen more clearly than in the multitude of new programmes for decentralised governance that are found in both southern and northern countries.

Part of the international donors' and NGOs' local development strategies involve building partnerships and communication channels with and between national institutions, local authorities, community organisations, civil society, the private sector, and citizens. These strategies also involve promoting policy and institutional reforms to enable the transfer of powers and financial resources to more effective and accountable local spheres of government. Popular education and communication activities methodologies are needed to strengthen citizens' awareness and responsibilities under new local governance legislation.

Monitoring and evaluation of the communication activities should be undertaken at multiple levels, and particularly in local communities. Fortunately, local authorities have increased their monitoring and evaluation activities in recent years, although most of such work is still conducted in-house.

\section{Anti-corruption, accountability and transparency}

Civil society organisations and citizens play a key role in fighting corruption. In so doing, they constitute an effective self-governance tool. The OECD, World Bank, EU, Transparency International, and other bodies widely recognise the role that an informed civil society plays in fighting corruption and advocating for greater accountability and transparency in government. But what does this mean from a communication standpoint?

Civil Society Organisations (CSOs) and the general public have taken advantage of multiple communication channels, both to support the monitoring processes and to denounce corrupt government practices. They have done so through various practices, including by encouraging ombudsmen and whistleblowers.

The EU identified communication as one of the linchpins of anticorruption efforts in countries seeking accession to EU. 'Communication on a Comprehensive EU Policy Against Corruption' ensures that independent media and the free flow of information are among the most important anti-corruption efforts a country can make. Communication also helps the process of demystify- 
ing and depersonalising government - opening up information, informing citizens of their legal rights in dealing with government, and publishing staff manuals which are easily accessible to departmental users, contractors, and think tanks. An increasing number of studies suggest that media prevalence can be linked to the improved delivery of government services, because media coverage creates pressure for accountability (Adsera, Boix \& Payne 2000; Besley \& Burgess 2003).

Efforts to fight corruption and realise transparency, however, have mainly concentrated on economic transparency at the level of governments and projects. Of equal importance is attention to transparency at the policy formulation level of development goals and projects. In as much as development goals are mostly determined by international agencies that are largely influenced by the North, the funding of development projects in countries of the global South are mainly based on Northern constructs of development. Development is primarily viewed within economic and political points of reference that are often in conflict with economic, social, cultural, or political points of reference of countries in the South. Transparency at the policy level requires the adoption of universal constructs of development that take into consideration cultural as well as societal particularities. For a discussion of the Kenyan case, see Andrew Muller (2001).

\section{Economic reforms and infrastructure for service delivery}

Economic reforms and infrastructures constitute a significant part of the donors' lending and technical assistance programs to developing countries. Such reforms go to the core of the norms around which societies are organised, thus affecting the relationship and informal interactions between institutions and citizens. Such reforms, therefore, require all parties to accept a significant change in beliefs and perceptions about the nature of public goods, and a new balance between government responsibility, public investment, and private-sector activities.

Economic reforms require a shift in the rights and responsibilities of all players, and call for the national mobilisation of civil servants, ministries, businesses, academics, media, unions, consumers, civil society, and nongovernmental organisations to move the economic reforms and infrastructure-building programs forward.

In this highly complex socio-political environment, economic reforms and infrastructure projects are under increased public scrutiny. Performance of communication activities based on product outputs (e.g. number of radio and TV spots, advertisements, etc.) is no longer sufficient to meet these new demands. Constituencies want to know more about how reforms can have a significant impact on poverty reduction and the economic participation wellbeing of all citizens. Traditionally, many infrastructure projects have been accompanied by controversy. In this respect, a communication role has often been that of damage control. Within the current development context, however, communication is expected to anticipate and prevent problems, not just chronicle their efforts. 


\section{Role of the media in good governance}

The role of the media is critical in promoting good governance through institutional monitoring. The media are critical elements on a country's institutional accountability and anticorruption efforts. They have a dual role to play: they not only raise public awareness about corruption, its causes, consequences and possible remedies, they also investigate and report incidences of corruption. The effectiveness of the media, in turn, depends on access to information and freedom of expression, a professional and ethical cadre of investigative journalists, and the availability of regular updates via short- or long-term training and education (Berger \& Matras 2007).

When the media are working well, they prevent corruption via their monitoring activities. Investigative journalism may reveal inequities and violations and, by doing so, reinforce social values. In a very practical sense, they may also reduce incidences of corruption in both the public and private sectors. By the same token, in an environment of free speech and a free press, the media perform a watchdog function and expose social injustices wherever they occur. In an open, pluralistic, and developed society, the media are a particularly effective tool for exposing and preventing corruption; they are successful at this, because corruption cases usually make the news.

\section{IN SEARCH OF MEDIA PERFORMANCE INDICATORS}

Puddephatt (2007) presents a comprehensive overview of the available diagnostic tools and performance indicators in the field of communication for development, especially the media's impact on democracy and governance. He concludes that the indicators developed for UNESCO may be able to avoid some of the pitfalls identified in other assessment systems. He presents five principal categories of media indicators, which provide an organising framework that can be adapted to the needs of media development initiatives in any given national context. 'The assumption is that to have a media environment that is supportive of democracy and good governance, all five categories will be positive' (Puddenphatt 2008: 10-11):

Category 1: A system of regulation and control conducive to freedom of expression, pluralism and diversity of the media: Existence of a legal, policy and regulatory framework which protects and promotes freedom of expression and information, based on international best practice standards and developed in participation with civil society.

Category 2: Plurality and diversity of media, a level economic playing field and transparency of ownership: The state actively promotes the development of the media sector in a manner which prevents undue concentration of ownership and ensures plurality and transparency of ownership and content across public, private and community media.

Category 3: Media as a platform for democratic discourse: The media, within a prevailing climate of self-regulation and respect for the journalistic profession, reflects and represents the 
diversity of views and interests in society, including those of marginalized groups. There is a high level of information and media literacy.

Category 4: Professional capacity building and supporting institutions that underpins freedom of expression, pluralism and diversity: Media workers have access to professional training and development, both vocational and academic, at all stages of their career, and the media sector as a whole is both monitored and supported by professional associations and civil society organizations.

Category 5: Infrastructural capacity is sufficient to support independent and pluralistic media: The media sector is characterized by high or rising levels of public access, including among marginalized groups, and efficient use of technology to gather and distribute news and information, appropriate to the local context.

\section{'KENYA'S VIBRANT AND CRITICAL MEDIA' (BBC 2008)}

How is the above to be interpreted in the context of Kenya? A brief and sketchy analysis of readily available sources (Abdi \& Deane 2008; BBC 2008; IREX 2007, Kabukuru 2008; Mukinda \& Muchire 2008; Mureithi \& Munyua 2006; Oriare Mbeki 2008) provides us with the following findings:

At the general development level, Kenya has embarked on a major long-term development plan called Vision 2030 (Government of Kenya 2007d). Assisted by the consultancy firm McKinsey, the National Economic and Social Council of Kenya - in collaboration with the Ministry of Planning and National Development, through an all-inclusive and participatory stakeholder consultative process - developed a new development blueprint for the period 2008 to 2030. It aims to transform Kenya 'into a new industrializing, multi-income country providing a high quality life to all its citizens by the year 2030' (Government of Kenya 2007d: 1).

In the meantime, the latest World Bank (2007: iii) report indicates that 'progress has been made but a challenging period lies ahead'. The report continues the Bank Group's strategic emphasis on growth and poverty reduction, but gives enhanced attention to equity and governance. Four recurrent themes remain relevant: (a) strengthening public sector management and accountability; (b) reducing the cost of doing business and improving the investment climate; (c) reducing vulnerability and strengthening communities; and (d) investing in people.

Pollin, wa Githinji \& Heintz (2007), in their report for the UNDP, emphasise that the need to eradicate extreme poverty and hunger (UN 2007: 1) is conditional to the employment issue: 'A high proportion of people working full time at jobs are still unable to support themselves and their families above a poverty-line level. This is why it is crucial to not simply focus on employment alone, but the quality of employment.' 
The situation at the media level has to be assessed from at least three perspectives. Media content is produced (a) in a culture-societal context (hence: normative theories); (b) in organizationalinstitutional settings (with differing private- versus public interests, and explicit or implicit ideologies); and (c) in 'media-specific'situations (hence: news values).

The Kenyan legal framework is comprehensively assessed and summarised by Peter Oriare Mbeki (2008: 8-9) in the following:

The mass media and communication sector in Kenya remains vulnerable to system-wide pressures. The recent post-election violence and the resulting ban on live broadcasting are just two recent examples of this. The causes of this are weak, irresolute and inadequate legal, regulatory and policy framework inherited from the colonial era. The growth and development of the mass media and communication has been slow, stunted, haphazard and often inconsistent with public and investor expectations over the years because of a disenabling legal and policy environment. Political, social, cultural, economic, globalization and technological forces influenced the legal, regulatory and policy environment throughout the history of Kenya.

The legal, regulatory and policy environment is still hostile to media and communication development but there is hope that it will get better if a better constitution is enacted, draconian laws repealed and new policies put in place.

Progressive laws governing media and communications in Kenya need to be firmly entrenched in the proposed Constitution to provide impetus for steady growth of the sector.

The government urgently needs a language policy that deals with the use of hate speech in media and during elections in particular. The proposed Ethnic Relations Commission would champion this. The broadcasting policy needs to integrate community media, public and private commercial broadcasting principles and regulatory framework. A comprehensive communication policy that addresses such important issues as media ownership and control, programming and local content, education and training, capacity building for community media among other issues is urgent (emphasis added, JS).

From the overviews provided by IREX (2008), Mureithi \& Munyua (2006), and especially Abdi \& Deane (2008: 2-3), we wish to highlight the following policy conclusions relevant to development policymakers:

- The media have shaped and will continue to play a central role in shaping Kenya's democracy. The recent record of the media, according to many within it, is that media has undermined as well as invigorated that democracy. An understanding of democracy and democratic governance in Kenya is not possible without a strong understanding of the media's role in the country. 
- The problem facing Kenya's media is not an excess of media freedom. It is a lack of it. Media freedom cannot, however, be described simply in terms of independence from government. Journalists and broadcasters face immense commercial and political constraints which are constraining their journalistic independence and integrity.

- Some local language radio stations have incited fear and hatred particularly at the height of the violence after the elections. Local language radio stations are routinely partisan and flout codes of ethics. Talk shows have provided the greatest opportunities for hate speech and talk show hosts are not trained in conflict reporting or moderation.

- More recently, most local language stations (and much of the rest of the media) appear to have been playing an important role in calming tension and promoting dialogue. A strengthening of such a role by a genuinely independent media will form a critical contribution as Kenya navigates the turbulent waters ahead of it.

- Training in general remains a major priority, although this is less a challenge of traditional journalistic training, and more one of training talk show hosts and others engaged in facilitating public debate. Training on conflict reporting may have been considered unnecessary in Kenya - now it should be considered an urgent need (see also Berger \& Matras 2007).

- The media policy and regulatory environment in Kenya will be the subject of considerable review and debate within Kenya in the near future. Such a debate should be encouraged, and particular attention could usefully be focused on a public interest approach to broadcasting and media.

- Media monitoring by civil society and research organisations has done a good deal to discourage the broadcast of hate speech by media organisations. Such monitoring is currently haphazard and could be more systematic and better supported.

- Community media has, despite its tiny size, emerged from this crisis with great credit and arguably provides a model for the future. It requires better, more strategic engagement and support in Kenya. This support is partly a question of policy engagement, partly one of financial, funding and sustainability models.

- The poor remuneration, status and safety of journalists are hampering a free and plural media. Substantial progress in strengthening the media will not be possible unless the working conditions of journalists are improved.

- There is no independent public service broadcaster in Kenya. If there had been, the scale of the violence and of the crisis may well have been much less severe. If there is a debate and a move in the country to transform $\mathrm{KBC}$ into one, it could usefully be intensively supported. 
- Kenya faces the most important public debate in its history. The media will be central to its character, conduct and its outcome. An inclusive and balanced debate may need financial support.

- Coordination, information sharing and long term strategic planning of media support within Kenya could be substantially improved, including in ensuring that external media support is both demand led and strategically coherent. Much capacity building of media over recent years has been donor led (focused for example on specific health or other issues) rather than addressing the core challenges facing media in Kenya.

\section{CONCLUSIONS}

We started by pointing out that there have historically been two dominant paradigms informing the communication for development sector. In recent years, a third paradigm has emerged: the multiplicity or participatory paradigm. Despite some re-orientations and shifts, the older paradigms have not 'vanished' as theories, and in fact there are still quite vocal applications of these.

However, the new multiplicity paradigm starts examining the processes of 'bottom-up' change, focusing on self-development of local communities. The basic assumption is that there are no countries or communities that function completely autonomously and that are completely selfsufficient, nor are there any nations whose development is exclusively determined by external factors. Every society and community is dependent in one way or another, both in form and in degree.

This also implies, as argued by Southern scholars like Kwame Anthony Appiah $(2005,2006)$, Shelton Gunaratne (2005), or Majid Tehranian (2007) that a cultural perspective has to be fully embraced. This may lead to what Appiah calls the cosmopolitan challenge:

If we accept the cosmopolitan challenge, we will tell our representatives that we want them to remember those strangers. Not because we are moved by their suffering - we may or may not be - but because we are responsive to what Adam Smith called 'reason, principle, conscience, the inhabitant of the beast'. The people of the richest nations can do better. This is a demand of simple morality. But it is one that will resonate more widely if we make our civilization more cosmopolitan. (Appiah 2006: 174).

Attention is also needed to critically analyse the content of development agendas. An understanding of the way in which development projects both encounter and transform power relationships within (and between) the multiple stakeholders who are impacted by such projects; and an understanding of the way in which communication plays a central part in building (or maintaining or changing) power relationships is needed.

Members ${ }^{1}$ of the Scientific Committee of the World Congress on Communication for Development (Rome, 25-27 October 2006) identified the following main challenges for communication 
for development and social change (Servaes 2007: 112-114) to be recognised as a field in its own right and to be adopted systematically in development initiatives:

1. Good governance, transparency, accountability and development communication go hand in hand. Good governance and a good government are not the same. Good governance is based on the participation of all people concerned. Decentralisation of governmental institutions does not necessarily imply people's participation. Decentralization does not always mean democratization. In reality the motives for decentralizing may hide a wish of central powers to get rid of certain responsibilities while tightening their control. This blurs the lines of accountability. For this reason, local media have a crucial role to play in facilitating a mutual understanding between those in power and the communities.

2. Participatory concepts in the context of communication for development can be complex and challenging. Communities consist of fluid interests and shifting relationships.

3. Participation can take place at different levels: (a) decision making; (b) benefits; (c) evaluation; and (d) implementation. Participation is about changing power relations. While empowering one group, it may do the opposite to another. Meaningful participation requires organization around common interests and awareness on how to handle power relations.

4. It is important to reinforce independent and pluralistic media to foster good governance and transparency. Print media can play a special role in society as they are sometimes more independent and pluralistic than radio and television. However, all media need to be sensitised and become more participatory. Currently there is often a gap between what media report and the realities of a country. Pure commercialism avoids tackling the crucial issues of a country because such issues do not sell. It undermines the role of media as watchdogs. Press freedom is never guaranteed, not even in a democracy.

5. Communication for development has not made full use of the potential of radio, which in some regions could be the most effective participatory tool. Radio has the highest penetration in many rural areas in developing countries. It is not too late to rediscover radio. In particular community radio (often linked to the global world through the Internet) has proven its ability to make participation effective and sustainable. Therefore, also ICTs are an important tool to facilitate good governance provided that application and operation systems are made available in local languages.

6. Policies and resources - communication for development initiatives need to be properly enabled by concerted actions, and adequate policies and resources. These should consider longer timescales. It is essential to bridge the digital divide by supporting community access to relevant information in their own language and at an affordable cost, for example through community telecentres/multimedia centers. This should also involve support for the production of content by the local communities. It is crucial to encourage the production of 
diverse local content in local languages for the media and ICTs, bearing in mind the potential of interactive technologies to carry multimedia content.

7. National governments should implement a legal and supportive framework favoring the right to free expression and the emergence of free and pluralistic information systems, including the recognition of the specific and crucial role of community media in providing access to communication for isolated and marginalised groups. There is a need to influence policy on communication for development through advocacy, not only with governments and international agencies but also within development agencies, private corporations and civil society partners, for communication for development to be successful.

8. Building alliances. There is a need for effective linkages which give voices to the poorest and have the ability to engage with policy and influence decision making on sustainable development. To this end, special attention should be given to fostering local, national and regional communication for development processes.

9. New global partnerships are necessary with the media, development agencies, universities and governments. It is important to identify possibilities for convergence and for complementing existing work and to coordinate and document such work via a truly independent scientific body.

\section{ENDNOTE}

1. Jan Servaes, Nicholas Carah, Martin Hadlow, Eric Louw, Pradip Thomas (University of Queensland), Silvia Balit (independent consultant), Maria Celeste Cadiz (University of the Philippines Los Banos), Nabil Dajani (American University of Beirut), Cees Hamelink (University of Amsterdam), Tom Jacobson (Temple University), Ullamaija Kivikuru (University of Helsinki), John Mayo (Florida State University), Rafael Obregon (Ohio University), Doug Storey (John Hopkins University), Thomas Tufte (Roskilde University), and Karin Gwinn Wilkins (University of Texas at Austin).

\section{REFERENCES}

Abdi, J. and J. Deane. 2008. The Kenyan 2007 elections and their aftermath: The role of media and communication. BBC World Service Trust Policy Briefing \#1, London, April.

Adsera, A., C. Boix and M. Payne. 2000. Are you being served?: Political accountability and quality of government, inter-American Development Bank, Research Department Working Papers Series, No. 438., Washington DC.

Appiah, K.A. 2005. The ethics of identity. Princeton, NJ: Princeton University Press. . 2006. Cosmopolitanism. Ethics in a world of strangers. London: Allen Lane.

Article 19. 2005. A model public service broadcasting law. London: Article 19.

BBC. 2008. Kenya's vibrant and critical media. http://newsvote.bbc.co.uk/mpapps/pagetools/print/news. bbc.co.uk/2/hi... (accessed 6/28/2008).

Beltran, L.R. 1993. Communication for development in Latin America: A forty years appraisal. In D. Nostbakken \& C. Morrow (eds), Cultural Expression in the Global Village. Penang: Southbound. 
Berger, M.T. 2004. The battle for Asia. London: Routledge-Curzon.

Berger, G. and C. Matras. 2007. Criteria and indicators for quality journalism training institutions \& identifying potential centres of excellence in journalism training in Africa. Paris: UNESCO.

Berqué, P., E. Foy and B. Girard. 1993. La passion radio. 23 expériences de radio participative et communautaire à travers le monde. Paris: Syros.

Berrigan, F.J. 1977. Access: Some Western models of community media. Paris: UNESCO. . 1979. Community communications. The role of community media in development. Paris: UNESCO.

Besley, T. and R. Burgess. 2003. The political economy of government responsiveness: Theory and evidence from India. The Quarterly Journal of Economics (November 2002): 1415-1451.

Boyd-Barrett, O. 1977. Media imperialism: Towards an international framework for the analysis of media systems. In J. Curran, M. Gurevitch \& J. Woollacott (eds), Mass communication and society. London: Arnold.

1982. Cultural dependency and the mass media. In M. Gurevitch, T. Bennett, J. Curran \& J. Woollacott (eds), Culture, society and the media. London: Methuen.

Braman, S. (ed). 1995. Horizons of the state: Information policy and power. Journal of Communication 45(4): 4-159.

Buckley, S., K. Duer, T. Mendel and S. O'Siochru. 2008. Broadcasting. Voice and accountability: A public interest approach to policy, law and regulation. Washington DC: World Bank Institute.

Carpentier, N., R. Lie and J. Servaes. 2001. Making community media work. Report prepared for UNESCO, Paris, $50 \mathrm{pp}+\mathrm{CD}$-Rom.

2003. Community media: Muting the democratic media discourse? Continuum, Journal of Media \& Cultural Studies 17(1): 51-68.

Chemers, M.M. 2000. Leadership research and theory: A functional integration. Group Dynamics: Theory Research and Practice 4: 27-43.

Chilcote, R. and D. Johnson (eds). 1983. Theories of development. Mode of production or dependency? Beverly Hills: Sage.

Costy, A. and S. Gilbert. 1998. Conflict prevention and the European Union: Mapping the actors, instruments, and institutions. London: International Alert.

Davis, A. 2006. A road map for monitoring and evaluation in the media development sector. In M. Harvey (ed), Media matters: Perspectives on advancing governance and development from the global forum for media development. London: Internews Europe.

De Cuellar, J.P. 1995. Our creative diversity. Report of the World Commission on Culture and Development. Paris: UNESCO.

DFID. 2001. Sustainable livelihoods guidance sheets, Section 2: Framework, Department of International Development (DFID), London. htpp://www.livelihoods.org/onfo/info_guidanceSheets.html (accessed 25 June 2007).

Dowden, R. 2008. Africa's leadership crisis. Time, June 23: 20.

Edelman, M. and A. Haugurud (eds) 2005. The anthropology of development and globalization. Oxford: Blackwell.

Figueroa, M.E., D.L. Kincaid, M. Rani and G. Lewis. 2002. Communication for social change: A framework for measuring the process and its outcomes. New York and Baltimore: The Rockefeller Foundation and Johns Hopkins Center for Communication Programs.

Fischer, D. 1982. The right to communicate. A status report. Paris: UNESCO. 
Fischer, D. and L.S. Harms (eds) 1983. The right to communicate. A new human right. Dublin: Boole Press.

Fox, E. 1988. Media and politics in Latin America. The struggle for democracy. London: Sage.

Fraser, C. and S. Restrepo-Estrada. 1998. Communicating for development. Human change for survival. London and New York: I.B. Tauris Publishers.

Galtung, J. 1994. Human rights in another key. Cambridge: Polity Press.

Girard, B. (ed) 1992. A passion for radio. Montreal: Black Rose Books.

Government of Kenya. 2007a. Master Plan for the Implementation of a National Integrated Monitoring and Evaluation System for Kenya 2007-2012: NIMES Keeping development on track, Monitoring \& Evaluation Directorate, Ministry of Planning \& National Development, Nairobi, July. . 2007b. The Third Annual Progress Report (2005-2006). Economic Recovery Strategy (2003-2007), Monitoring \& Evaluation Directorate, Ministry of Planning \& National Development, Nairobi, August.

. 2007c. The ERS Mid-Term Review, Monitoring \& Evaluation Directorate, Ministry of Planning \& National Development, Nairobi, August. . 2007d. Kenya Vision 2030, National Economic and Social Council of Kenya (NESC), Office of the President, Nairobi.

Gumucio-Dragon, A. and T. Tufte (eds) 2006. Communication for social change anthology: Historical and contemporary readings. South Orange, NJ.: CFSC Consortium.

Gunaratne, S. 2005. The Dao of the press. A humanocentric theory. Cresskill, NJ.: Hampton Press.

Hamelink, C.J. 1994. The politics of world communication. A human rights perspective. London: Sage.

2004. Human rights for communicators. Creskill: Hampton Press.

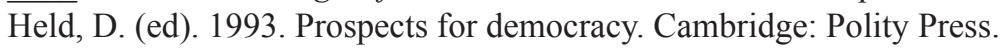
1995. Democracy and the global order. From the modern state to cosmopolitan governance. Cambridge: Polity Press.

Hoover, S., S. Venturelli and D Wagner. 1993. Trends in global communication policy-making: Lessons from the Asian Case. Asian Journal of Communication 3(1): 103-132.

Hudson, H.E. 2006. From rural village to global village: Telecommunications for development in the Information Age. Mahwah, NJ.: Lawrence Erlbaum Associates.

Husband, C. (ed). 1994. A richer vision. The development of ethnic minority media in Western democracies. Paris: UNESCO.

Inagaki, N. 2007. Communicating the impact of communication for development. Recent trends in empirical research. World Bank Working Paper No. 120. Washington DC: The World Bank.

IREX. 2008. Media sustainability index 2006/2007. The development of sustainable independent media in Africa. Washington, DC: IREX. (www.irex.org/msi)

Kabukuru, W. 2008. Kenya. Spare us the agony and bias. New African 42(474, June): 32-33.

Kay, C. 1989. Latin American theories of development and underdevelopment. London: Routledge.

Knapp, M. and J. Daly (eds) 2002. Handbook of interpersonal communication. London: Sage.

Lee, P. (ed). 1995. The democratization of communication. London: WACC. . 2004. Many voices, one vision. The right to communicate in practice. Penang: Southbound and London: WACC.

Lerner, D. 1958. The passing of traditional society. Modernizing the Middle East. New York: Free Press.

Lewis, P. (ed) 1993. Alternative media: Linking global and local. Paris: UNESCO. 
2008. Promoting social cohesion. The role of community media. Strasbourg: Council of Europe. Librero, F. 2006. Preface: Some challenges in the practice of development broadcasting. In L.P. Manyozo, Doing radio with local people: A development broadcasting approach, 9-12. Unpublished manuscript.

Lie, R. 2003. Spaces of intercultural communication. An interdisciplinary introduction to communication, culture, and globalizing/localizing identities. IAMCR Book Series. Cresskill, NJ.: Hampton Press.

Lord, R.G. and D.J. Brown. 2004. Leadership processes and follower self-identity. Mahwah, NJ.: Lawrence Erlbaum Associates.

MacBride, S. (ed). 1980. Many voices, one world: Communication and society. Today and tomorrow. Paris: UNESCO.

Manyozo, L.P. 2006. Doing radio with local people: A development broadcasting approach. Unpublished manuscript.

Martin-Barbero, J. 1993. Communication, culture and hegemony. From the media to mediations. London: Sage and New Delhi: Newbury Park.

Mayo, J. and J. Servaes (eds) 1994. Approaches to development communication. A resource and orientation kit, vols. 1 and 2. Paris/New York: UNESCO/UNFPA.

McKee, N., E. Manoncourt, C. Saik Yoon and R. Carnegie. 2000. Involving people evolving behaviour. Penang: Southbound \& UNICEF.

McQuail, D. 2005. McQuail's Mass Comunication Theory, fifth edition. London: Sage.

Mehmet, O. 1995. Westernizing the Third World. Eurocentricity of economic development theories. London: Routledge.

Melkote, S. 1991. Communication for development in the Third World. Theory and practice. New Delhi: Sage.

Miller, D. (ed) 1995. Worlds apart. Modernity through the prism of the local. London: Routledge.

Mukinda, F. and W. Muchire. 2008. Opinion polls blamed for election chaos. Daily Nation, Tuesday, July 1: 2 .

Muller, A. (ed) 2001. The link between corruption and poverty: Lessons from Kenya. Case studies. Nairobi: African Centre for Economic Growth.

Mureithi, M. and A.W. Munyua. 2006. Making ICT work for the poor in Kenya: In search of an entry strategy framework. Nairobi: United Nations Development Programme (UNDP).

Nederveen Pieterse, J. and B. Parekh (eds) 1995. The decolonization of imagination: Culture, knowledge and power. London: Zed Books.

NEPAD. 2007. African Peer Review Mechanism (APRM): Kenya Report. Nairobi: New Partnership for Africa's Development (NEPAD).

Norris, P. and D. Zinnbauer. 2002. Giving voice to the voiceless: Good governance, human development and mass communications. New York: UNDP Human Development Report Office.

Nyamnjoh, F. 2005. Africa's media, democracy and the politics of belonging. London: Zed Books. . 2007. Africa in the new millennium: Interrogating Barbie democracy. Communication for Development and Social Change 1(2): 105-111.

Oepen, M. (ed) 1995. Media support and development communication in a world of change. New answers to old questions? Bad Honnef: Horlemann.

Oriare Mbeki, P. 2008. The media, legal, regulatory and policy environment in Kenya. A historical briefing paper. London: BBC World Service Trust.

PANOS. 2007a. Mapping declarations and statements on communication for development. Promoting dialogue, debate and change. London: PANOS. 
PANOS. 2007b. At the heart of change. The role of communication in sustainable development. London: PANOS.

Pollin, R., M. wa Githinji and J. Heintz. 2007. An employment-targeted economic program for Kenya. New York: United Nations Development Programme (UNDP).

Puddenphatt, A. 2007. Defining indicators for media development. A background paper. Paris: UNESCO. . 2008. Diagnostic tools and performance indicators. Paper presented at the Harvard-World Bank Workshop on The Role of the News Media in the Governance Reform Agenda, JFK School, Cambridge, Boston, 29-31 May.

Renn, O., T. Webler and P. Wiedemann. 1995. Fairness and competence in citizen participation: Evaluating models for environmental discourse. Dordrecht: Kluwer.

Rogers, E.M. 1962. Diffusion of innovations. New York: Free Press. 1983. The diffusion of innovations, third edition. New York: The Free Press. . 2003. The diffusion of innovations, fifth edition. New York: Free Press.

Schramm, W. 1964. Mass media and national development. The role of information in the developing countries. Stanford: Stanford University Press.

Sen, A. 2004. Cultural liberty and human development. In S. Fukuda-Parr (ed), Human development report: Cultural liberty in today's diverse world. New York: United Nations Development Programme (UNDP).

Servaes, J. 1993. Development communication in action: Report of the Inter-Agency Meeting on Advocacy Strategies for Health and Development. WHO Conference, Geneva, 9-13 November 1992, World Health Organisation (WHO), Geneva, 36pp.

. 1999. Communication for development. One world, multiple cultures. Cresskill, NJ.: Hampton Press.

2000. Advocacy strategies for development communication. In J. Servaes (ed), Walking on the other side of the information highway. Communication, culture and development in the 21st century, 103-118. Penang: Southbound.

. 2003. Approaches to development. Studies on Communication for Development. Paris: UNESCO.

Servaes, J. (ed). 2007. Communication for development. Making a difference. Background paper for the World Congress on Communication for Development, Rome, 25-27 October 2006. Washington, DC: World Bank-FAO-Communication Initiative. .2008. Communication for development and social change. Los Angeles, London, New Delhi and Singapore: Sage.

Servaes, J. and S. Liu (eds). 2007. Moving targets. Mapping the paths between communication, technology and social change in communities. Penang: Southbound.

Servaes, J. and P. Malikhao. 2007. Communication and sustainable development. In J. Servaes \& S. Liu (eds), Moving targets. Mapping the paths between communication, technology and social change in communities, 11-42. Penang: Southbound.

Sparks, C. 2007. Globalization, development and the mass media. Los Angeles, London, New Delhi, Singapore: Sage.

Stiglitz, J. 1998. Towards a new paradigm for development: Strategies, policies, and processes. Prebisch Lecture at UNCTAD, Geneva, 19 October, 46pp.

Tehranian, M. 1979. Development theory and communication policy. The changing paradigm. In M. Voigt \& G. Hanneman (eds), Progress in communication sciences, Vol. 1. Norwood: Ablex. 
.2007. Rethinking civilization. Resolving conflict in the human family. London: Routledge.

UNESCO. 2005. Media and good governance. www.unesco.org

United Nations. 2000. United Nations Millennium Declaration. http://www.ohchr.org/english/law/ millennium.htm (accessed 5 November 2006). . 2007. The Millennium Development Goals Report 2007. New York: UN.

United Nations Development Program. 2004. Human Development Report 2003. Cultural liberty in today's diverse world. New York: Oxford University Press.

2006. Communication for empowerment: Developing media strategies in support of vulnerable groups. Oslo, Norway. www.worldbank.org/wbi/news/docs/Severinoonfreepress.htm

United Nations Economic Commission for Africa. 2005. Striving for good governance in Africa. Addis Ababa: UNECA.

Wallack, L., L. Dorfman, D. Jernigan and M.Themba. 1993. Media advocacy and public health. Power for Intervention. Newbury Park, Sage.

World Bank. 2006a. Global Monitoring Report 2006. Washington DC: World Bank. . 2006b http://web.worldbank.org/WBSITE/EXTERNAL/TOPICS/EXTDEVCOMMENG/0,,men uPK:34000201 pagePK:34000189 piPK:34000199 theSitePK:423815,00.html

2007. The International Development Association, The International Finance Corporation and The Multilateral Investment Guarantee Agency Country Assistance Strategy Progress Report for The Republic Of Kenya for the Period Fy04-O8, February 16, 2007, Report No. 38055-KE. Washington DC: World Bank. 